\title{
Mycoendophytes and its Antifungal Efficacy against Macrophomina phaseolina (Tassi) Goid. Incitant of Mulberry (Morus indica L.) Charcoal Rot
}

\author{
A. Maria Joncy ${ }^{1}$, K. Angappan ${ }^{2 *}$ and S. Nakkeeran ${ }^{2}$ \\ ${ }^{1}$ Department of Sericulture, Forest College and Research Institute, Tamil Nadu Agricultural \\ University, Mettupalayam - 641 301, India \\ ${ }^{2}$ Department of Plant Pathology, Center for Plant Protection Studies, Tamil Nadu \\ Agricultural University, Coimbatore - 641 003, India \\ *Corresponding author
}

\section{A B S T R A C T}

\begin{tabular}{|l|}
\hline Ke y w o r d s \\
Mulberry, \\
Mycoendophytes, \\
Charcoal rot, \\
Antifungal, \\
Interaction \\
\hline Article Info \\
\hline $\begin{array}{l}\text { Accepted: } \\
\text { 20 June } 2019 \\
\text { Available Online: } \\
\text { 10 July } 2019\end{array}$ \\
\hline
\end{tabular}

\section{Introduction}

Mulberry (Morus indica) is the elite food plant of the silkworm, Bombyx mori L. (Zhang et al., 2011) and is often affected by a number of diseases and herbivores, which hampered leaf quality and productivity (Kumar and Gupta, 2004). Mulberry diseases caused 5-10 per cent loss in leaf yield by defoliation and additional loss of 20-25 per cent by deterioration in leaf quality (Sukumar and Padma, 1999). The mulberry being a
Thirty fungal endophytic isolates were recovered from leaf, stem, root and inflorescence of mulberry plant and the morphological characterization was done. The antifungal potential of isolated mycoendophytes against Macrophomina phaseolina was evaluated in vitro by dual culture technique and revealed that ENF20 isolate reduced the mycelial growth by 82.22 per cent over control followed by ENF12 (80.56 per cent), ENF11 (77.78 per cent), ENF13 (76.11 per cent). The endophyte-pathogen interaction study elucidated the mechanisms of antagonism by antibiosis, competition for substrate, hyperparasitism and neutral reaction. The endophytic fungi interaction with $M$. phaseolina revealed that ENF12 isolate exhibited antibiosis, ENF25 showed competition. Likewise, ENF13, ENF19 and ENF20 expressed mycoparasitism besides ENF3 unveiled neutral reaction. 
to treat this disease could be hazardous to silkworms (Ji et al., 2008). Hence, there is a need to explore microbial antagonists like endophytes for management of diseases is unavoidable. Endophytes are microorganisms that colonize on healthy plant tissues intercellularly or intracellularly without causing any apparent symptoms of disease (Wilson, 1995). Mycoendophytes (fungal endophytes) are the most frequently occurring endophytes but relatively less studied and offer tremendous potential of novel secondary metabolites for exploitation in the medicine, pharmaceutical and agriculture industries (Strobel, 2018). However, information and research work on the mulberry endophytes and their use in biological control of mulberry diseases are very scanty. Hence, this study focused on the isolation of mycoendophytes associated with $M$. indica and screening them for antifungal activity against charcoal rot pathogen $M$. phaseolina.

\section{Materials and Methods}

\section{Collection and surface sterilization of plant samples}

The plant samples were collected from $M$. indica, V1 variety from Forest College and Research Institute, Mettupalayam. The fresh plant materials were used for isolation work to reduce the chances of contamination. The collected plant samples were subjected to surface sterilization within a few hours after sampling.

The surface sterilization of collected plant samples was done according to the method described by Petrini (1986) with modifications. The samples were thoroughly washed in running tap water for 10 minutes to remove the soil particles and adhered debris and finally washed with distilled water. Then the samples were cut into small pieces by a sterilized blade under aseptic conditions followed by washing the samples with Tween 20 (1 drop in $200 \mathrm{ml}$ of Sterile Distilled Water [SDW]) for one minute subsequently samples were rinsed with SDW for 3 times. Each sample was surface sterilized with 70 per cent ethanol for one minute later dipped in 2 per cent sodium hypochlorite solution for two minutes. Finally, samples were immersed in 0.1 per cent mercuric chloride for 30 seconds and the excess mercuric chloride was removed by rinsing with SDW for three times.

\section{Test for effectiveness of surface sterilization}

The aliquot of finally rinsed SDW was spread on PDA in Petri plates to confirm the effectiveness of sterilization process (Schulz et al., 1993).

\section{Isolation and morphological characterization of mycoendophytes}

The surface sterilized samples were macerated with $1 \mathrm{ml}$ of SDW in a sterile mortar and pestle, and each sample was serially diluted in test tubes containing $9 \mathrm{ml}$ of SDW. The dilutions of $10^{-4}$ and $10^{-5}$ were plated on Petri plates containing PDA medium. The plates were then incubated at $28 \pm 2{ }^{\circ} \mathrm{C}$ for 10 days and observed for fungal growth. Each colony obtained was subcultured on PDA slants and maintained for further use (Thangavelu and Gopi, 2015).

The isolated fungi were identified on the basis of morphological characteristics according to Domsch et al. (1980). Morphological identification was done in consonance with standard taxonomic key included colony growth, color, texture, pigmentation and growth rate.

\section{In vitro antifungal assay}

The isolated endophytes were screened for in vitro antagonistic activity against 
M. phaseolina by using dual culture technique (Dennis and Webster, 1971). In this method, 5 $\mathrm{mm}$ size discs of culture of endophytic isolates (5 days old culture) and simultaneously the same size of another disc having $M$. phaseolina (5 days old culture) was placed opposite to each other and close to the periphery of $90 \mathrm{~mm}$ Petri plates containing PDA. The plates inoculated only with the pathogen served as control. Three replications were maintained for each treatment. The plates were incubated at $28 \pm 2{ }^{\circ} \mathrm{C}$ until 100 per cent growth coverage in control. After the incubation period, the area between the two colonies at the interaction point was measured. The inhibition percentage was calculated using the formula given by Fokkema (1976).

Inhibition percentage $=\frac{\mathrm{C}-\mathrm{T}}{\mathrm{C}} \times 100$

Here, ' $\mathrm{C}$ ' represents the growth diameter of the pathogen in the control plate and ' $\mathrm{T}$ ' represents the pathogen diameter growth on the dual plate, where both the test endophyte and pathogen were inoculated.

\section{Endophyte-pathogen interaction}

From the visual interpretation of in vitro dual culture technique, the type of interaction between an endophyte and pathogen was evaluated according to the method followed by Mejia et al. (2008).

\section{Statistical analysis}

The Completely Randomized block Design method was adopted. All multiple comparisons were first subjected to Analysis of Variance (ANOVA). Duncan's multiple range test (DMRT) (Duncan, 1955) was applied to the transformed values and then transferred to the original means (Gomez and Gomez, 1984). The data were analyzed statistically by using software package SPSS 16.0 Command Syntax Reference.

\section{Results and Discussion}

\section{Isolation and identification of endophytic fungi}

The endophytic fungi from mulberry ( $M$. indica, variety: V1) were explored and their morphological characterization was done. A total of 30 endophytic fungal isolates were obtained from healthy tissues of $M$. indica. Among them, 13 isolates from leaf, 3 from stem, 13 from root and 1 from inflorescence were isolated. No microbial growth was observed on plates inoculated with finally rinsed SDW which proved the effectiveness of sterilization. The isolation and characterization of fungal endophytes from various plants were performed by several workers (Kannan et al., 2017; Yu et al., 2018; Lu et al., 2012). The efficiency of surface sterilization was proved by Ramalashmi et al. (2018).

The morphological characteristics of isolated fungal endophytes were observed. Majority of the young fungal colonies were appeared in whitish shade, whereas older colonies exhibited in white with different shades of colors. Similarly, most of the colony reverse colors of the isolates were seemed to be in creamy to white shades except ENF7, ENF8, ENF9, ENF11, ENF12, ENF14, ENF20, ENF22 and ENF25. The texture of the isolates was generally noticed as velvety, cottony and rarely powdery in nature. Among all isolates, ENF11, ENF12 and ENF16 were produced yellow pigmentation over the media. The growth rate of the endophytic fungal isolates was ranges from very slow to medium (Table 1). The morphological characterization of endophytic fungal isolates was carried out by Tolulope et al., (2015) suggested that the endophytic fungal colonies were initially white in color that became dark 
with later stages of growth. The colony morphological character such as texture, colony reverse and pigmentation has also been studied according to Nisa et al., (2018).

\section{In vitro screening of endophytic fungal isolates against $M$. phaseolina}

The thirty isolated fungal endophytes were individually screened against mulberry charcoal rot pathogen, $M$. phaseolina. In dual plate assay, the minimum mycelial growth of pathogen was noticed in ENF20 isolate by 16 mm diameter. ENF19 and ENF11 recorded the mycelial growth of $17.50 \mathrm{~mm}$ and 18.00 $\mathrm{mm}$ respectively. ENF7 (22.50 mm), ENF12 $(20.00 \mathrm{~mm})$ and ENF13 $(21.50 \mathrm{~mm})$ isolates also showed inhibition of pathogen growth (Plate 1).

Among all, the ENF20 isolate showed maximum growth inhibition of 82.22 per cent over control followed by ENF12 (80.56 per cent), ENF11 (77.78 per cent), ENF13 (76.11 per cent) inhibited the growth of pathogen. The ENF7 isolate exhibited 75 per cent of growth inhibition next to ENF9 (75.56 per cent).

The minimum growth inhibition was noticed in ENF26 (27.23 per cent) (Table 2). Molecular characterization of the best performing endophytes viz., ENF7, ENF9, ENF11, ENF12, ENF13, ENF19, ENF20 and ENF25 are to be carried out to reveal their identity.

Based on the in vitro assay, nearly eight isolates had excellent antifungal activity (>70 per cent) against $M$. phaseolina followed by ten isolates had high activity (50-70 per cent). The remaining twelve isolates were grouped under the category of moderate antifungal activity (20-50 per cent). The antifungal nature of endophytic fungal isolates was reported by several workers. Yu et al., (2018) evaluated the antifungal activity of endophytic fungal isolate Oidium sp. (ty-64) isolated from Camellia oleifera had strong inhibitory action against anthracnose pathogen. Aramsirirujiwet et al., (2016) studied the antagonistic behaviour of endophytic fungal isolates of rainbow plant against five plant pathogenic fungi (Fusarium oxysporum, Sclerotium rolfsii, Rhizoctonia sp., Alternaria brassicicola and Phytophthora palmivora) by dual culture technique.

\section{Endophyte-pathogen interaction}

Dual culture tests revealed that isolated endophytes reduced the growth of pathogen in vitro. The visual assessment of the interactions between endophytes and pathogen suggested that endophytes could antagonize the pathogen through several mechanisms such as antibiosis, competition for substrate, mycoparasitism and neutral growth.

Based on the growth responses in dual plate, the interaction between endophyte and pathogen was classified into four groups such as antibiosis (chemical reaction) with presence of reactive zone, competition for substrate thus forms the faster growth of one fungus, mycoparasitism when one fungi that have the ability to parasite other fungi and neutral or intermingling growth which had no effect on inhibition (Mejia et al., 2008).

In dual plate, growth of the pathogen was inhibited by endophytic fungi, ENF12 isolate through antibiosis mechanism. It was revealed that the endophytic fungi produced some biologically active compounds which inhibited the growth of pathogen. The antibiosis mechanism between endophytic fungi, Monographella nivalis and Dutch elm disease pathogen, Ophiostoma novo-ulmi was explained by Blumenstein (2015). 
Table.1 Morphological characteristics of endophytic fungal isolates of Morus indica L

\begin{tabular}{|c|c|c|c|c|c|c|c|c|}
\hline \multirow[t]{2}{*}{ S. No. } & \multirow{2}{*}{$\begin{array}{l}\text { Fungal } \\
\text { isolates }\end{array}$} & \multirow{2}{*}{$\begin{array}{c}\text { Plant } \\
\text { part used }\end{array}$} & \multicolumn{2}{|c|}{ Colony observation } & \multirow{2}{*}{$\begin{array}{l}\text { Colony } \\
\text { reverse }\end{array}$} & \multirow[t]{2}{*}{ Texture } & \multirow[t]{2}{*}{ Pigmentation } & \multirow{2}{*}{$\begin{array}{l}\text { Growth } \\
\text { rate }\end{array}$} \\
\hline & & & Young colony & Old colony & & & & \\
\hline 1 & ENF1 & Leaf & White & White & Cream & Velvety & No pigmentation & Medium \\
\hline 2 & ENF2 & Stem & White & $\begin{array}{l}\text { White with small } \\
\text { knots }\end{array}$ & White & Cottony & No pigmentation & Medium \\
\hline 3 & ENF3 & Stem & White & White & Cream & Cottony & No pigmentation & Medium \\
\hline 4 & ENF4 & Root & White & Greyish white & Grey & Cottony & No pigmentation & Medium \\
\hline 5 & ENF5 & Leaf & Olive green & Green & Cream & Powdery & No pigmentation & Slow \\
\hline 6 & ENF6 & Root & White & $\begin{array}{l}\text { White with } \\
\text { gummy exudates }\end{array}$ & White & Velvety & No pigmentation & Medium \\
\hline 7 & ENF7 & Root & $\begin{array}{l}\text { Yellow centre with } \\
\text { white margins }\end{array}$ & Yellow & Yellow & Velvety & No pigmentation & Medium \\
\hline 8 & ENF8 & Leaf & $\begin{array}{l}\text { Fern green shade centre } \\
\text { with white margins }\end{array}$ & Dark green & Pink & Velvety & No pigmentation & Medium \\
\hline 9 & ENF9 & Root & $\begin{array}{l}\text { Grey with crateriform } \\
\text { elevation }\end{array}$ & Greyish black & Black & Powdery & No pigmentation & Slow \\
\hline 10 & ENF10 & Root & $\begin{array}{l}\text { Emerald green centre } \\
\text { with white margins }\end{array}$ & Dark green & White & Velvety & No pigmentation & Slow \\
\hline 11 & ENF11 & Root & $\begin{array}{l}\text { Sandal yellow centre } \\
\text { with white margins and } \\
\text { crateriform elevation }\end{array}$ & $\begin{array}{l}\text { Dark sandal with } \\
\text { golden exudates }\end{array}$ & Yellow & Cottony & Yellow & Slow \\
\hline 12 & ENF12 & Leaf & $\begin{array}{l}\text { Sandal with spiral } \\
\text { topography }\end{array}$ & Brown & Yellow & Powdery & Yellow & Slow \\
\hline 13 & ENF13 & Stem & $\begin{array}{l}\text { Olive green with white } \\
\text { margins }\end{array}$ & Dark green & Cream & Powdery & No pigmentation & Slow \\
\hline 14 & ENF14 & Root & Grey with white & Greyish black & Black & Cottony & No pigmentation & Slow \\
\hline 15 & ENF15 & Leaf & White & $\begin{array}{l}\text { White with } \\
\text { orange resting } \\
\text { spores }\end{array}$ & White & Cottony & No pigmentation & Medium \\
\hline
\end{tabular}




\begin{tabular}{|c|c|c|c|c|c|c|c|c|}
\hline 16 & ENF16 & Leaf & Light green & Olive green & Cream & Powdery & Yellow & Medium \\
\hline 17 & ENF17 & Root & White & Snow white & White & Velvety & No pigmentation & Medium \\
\hline 18 & ENF18 & Leaf & Grey & Greyish black & Grey & Velvety & No pigmentation & Medium \\
\hline 19 & ENF19 & Root & White & White & White & Velvety & No pigmentation & Medium \\
\hline 20 & ENF20 & Flower & White & Greyish white & $\begin{array}{l}\text { Greyish } \\
\text { black }\end{array}$ & Velvety & No pigmentation & Medium \\
\hline 21 & ENF21 & Root & White & White & White & Cottony & No pigmentation & Medium \\
\hline 22 & ENF22 & Leaf & $\begin{array}{l}\text { White with brown } \\
\text { exudates and } \\
\text { filamentous/flower like } \\
\text { mycelium }\end{array}$ & Greyish white & Black & Velvety & No pigmentation & Slow \\
\hline 23 & ENF23 & Root & White & White & Cream & Cottony & No pigmentation & Slow \\
\hline 24 & ENF24 & Leaf & White & $\begin{array}{l}\text { White with } \\
\text { blackish grey }\end{array}$ & Grey & Velvety & No pigmentation & Medium \\
\hline 25 & ENF25 & Root & $\begin{array}{l}\text { Green with white } \\
\text { margins }\end{array}$ & Dark green & Green & Powdery & No pigmentation & Slow \\
\hline 26 & ENF26 & Leaf & White & $\begin{array}{l}\text { Whitish yellow } \\
\text { with brown } \\
\text { gummy exudates }\end{array}$ & Cream & Velvety & No pigmentation & Medium \\
\hline 27 & ENF27 & Root & Grey & Greyish green & Grey & Cottony & No pigmentation & Slow \\
\hline 28 & ENF28 & Leaf & White & $\begin{array}{l}\text { Snow white with } \\
\text { spiral } \\
\text { morphology and } \\
\text { with White } \\
\text { exudates }\end{array}$ & White & Velvety & No pigmentation & Medium \\
\hline 29 & ENF29 & Leaf & White & Whitish green & $\begin{array}{l}\text { Cream } \\
\text { colour }\end{array}$ & Powdery & No pigmentation & Very slow \\
\hline 30 & ENF30 & Leaf & White & Whitish green & $\begin{array}{l}\text { Whitish } \\
\text { yellow }\end{array}$ & Cottony & No pigmentation & Slow \\
\hline
\end{tabular}


Table.2 In vitro antagonistic activity of endophytic fungal isolates against Macrophomina phaseolina

\begin{tabular}{|c|c|c|}
\hline Isolate No. & $\begin{array}{l}\text { Mycelial growth of pathogen } \\
(\mathbf{m m})\end{array}$ & $\begin{array}{c}\text { Per cent growth inhibition over } \\
\text { control }\end{array}$ \\
\hline ENF1 & $\begin{array}{c}37.00 \\
(6.08)^{\mathrm{efg}}\end{array}$ & $\begin{array}{c}58.89 \\
(50.12)\end{array}$ \\
\hline ENF2 & $\begin{array}{c}37.50 \\
(6.12)^{\mathrm{efg}}\end{array}$ & $\begin{array}{c}58.34 \\
(49.80)\end{array}$ \\
\hline ENF3 & $\begin{array}{c}55.00 \\
(7.42)^{\mathrm{ijk}}\end{array}$ & $\begin{array}{c}38.89 \\
(38.58)\end{array}$ \\
\hline ENF4 & $\begin{array}{l}33.50 \\
(5.79)^{\text {def }}\end{array}$ & $\begin{array}{c}62.78 \\
(52.40)\end{array}$ \\
\hline ENF5 & $\begin{array}{l}38.00 \\
(6.16)^{\mathrm{efg}}\end{array}$ & $\begin{array}{c}57.78 \\
(49.48)\end{array}$ \\
\hline ENF6 & $\begin{array}{l}45.50 \\
(6.75)^{\mathrm{hi}}\end{array}$ & $\begin{array}{c}49.45 \\
(44.68)\end{array}$ \\
\hline ENF7 & $\begin{array}{c}22.50 \\
(4.74)^{\mathrm{abc}}\end{array}$ & $\begin{array}{c}75.00 \\
(60.00)\end{array}$ \\
\hline ENF8 & $\begin{array}{c}54.00 \\
(7.35)^{\mathrm{ij}}\end{array}$ & $\begin{array}{c}40.00 \\
(39.23)\end{array}$ \\
\hline ENF9 & $\begin{array}{c}24.00 \\
(4.90)^{\mathrm{abcd}}\end{array}$ & $\begin{array}{c}73.33 \\
(58.91)\end{array}$ \\
\hline ENF10 & $\begin{array}{l}35.00 \\
(5.92)^{\mathrm{efg}}\end{array}$ & $\begin{array}{c}61.11 \\
(51.42)\end{array}$ \\
\hline ENF11 & $\begin{array}{c}17.50 \\
(4.18)^{\mathrm{ab}}\end{array}$ & $\begin{array}{c}80.56 \\
(63.83)\end{array}$ \\
\hline ENF12 & $\begin{array}{c}20.00 \\
(4.47)^{\mathrm{abc}}\end{array}$ & $\begin{array}{c}77.78 \\
(61.88)\end{array}$ \\
\hline ENF13 & $\begin{array}{c}21.50 \\
(4.64)^{\mathrm{abc}}\end{array}$ & $\begin{array}{c}76.11 \\
(60.74)\end{array}$ \\
\hline ENF14 & $\begin{array}{l}36.50 \\
(6.04)^{\mathrm{efg}}\end{array}$ & $\begin{array}{c}59.45 \\
(50.44)\end{array}$ \\
\hline ENF15 & $\begin{array}{c}59.50 \\
(7.71)^{\mathrm{jk}}\end{array}$ & $\begin{array}{c}33.89 \\
(35.60)\end{array}$ \\
\hline ENF16 & $\begin{array}{c}23.50 \\
(4.85)^{\mathrm{abcd}}\end{array}$ & $\begin{array}{c}73.89 \\
(59.27)\end{array}$ \\
\hline ENF17 & $\begin{array}{c}40.50 \\
(6.36)^{\mathrm{fg}}\end{array}$ & $\begin{array}{c}55.00 \\
(47.87)\end{array}$ \\
\hline ENF18 & $\begin{array}{c}31.00 \\
(5.57)^{\text {cdef }}\end{array}$ & $\begin{array}{c}65.56 \\
(54.06)\end{array}$ \\
\hline ENF19 & $\begin{array}{c}18.00 \\
(4.24)^{\mathrm{ab}}\end{array}$ & $\begin{array}{c}55.00 \\
(47.87)\end{array}$ \\
\hline ENF20 & $\begin{array}{c}16.00 \\
(4.00)^{\mathrm{a}}\end{array}$ & $\begin{array}{c}82.22 \\
(65.06)\end{array}$ \\
\hline
\end{tabular}




\begin{tabular}{|c|c|c|}
\hline ENF21 & 52.00 & 42.22 \\
& $(7.2)^{\mathrm{ij}}$ & $(40.52)$ \\
\hline ENF22 & 58.50 & 35.00 \\
& $(7.65)^{\mathrm{jk}}$ & $(36.27)$ \\
\hline ENF23 & 54.00 & 40.00 \\
& $(7.35)^{\mathrm{ij}}$ & $(39.23)$ \\
\hline ENF24 & 60.50 & 32.78 \\
& $(7.78)^{\mathrm{jk}}$ & $(34.92)$ \\
\hline ENF25 & 23.50 & 73.89 \\
& $(4.85)^{\mathrm{abcd}}$ & $(59.27)$ \\
\hline ENF26 & 65.50 & 27.23 \\
& $(8.09)^{\mathrm{k}}$ & $(31.45)$ \\
\hline ENF27 & 59.00 & 34.45 \\
& $\left(7.68^{\mathrm{jk}}\right.$ & $(35.94)$ \\
\hline ENF28 & 60.00 & 33.34 \\
& $\left(7.75^{\mathrm{jk}}\right.$ & $(35.27)$ \\
\hline ENF29 & 57.00 & 36.67 \\
& $\left(7.55^{\mathrm{jk}}\right.$ & $(37.27)$ \\
\hline ENF30 & 28.00 & 68.89 \\
& $(5.29)^{\mathrm{bcde}}$ & $(50.12)$ \\
\hline Control & 90.00 & 0.00 \\
& $(9.49)^{\mathrm{l}}$ & $(49.80)$ \\
\hline
\end{tabular}

Values are mean of three replications;

Means followed by a common letter are not significantly different at 5\% level by DMRT;

Values in the parentheses are square root and arcsine transformed values respectively

Plate.1 In vitro screening of endophytic fungal isolates against $M$. phaseolina by dual culture assay
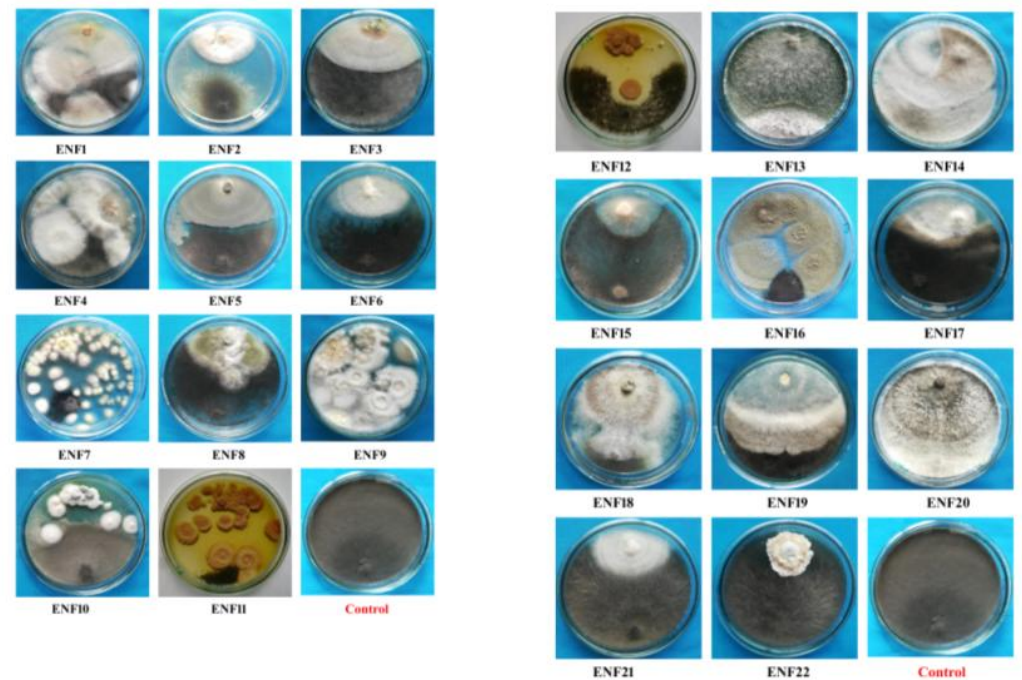
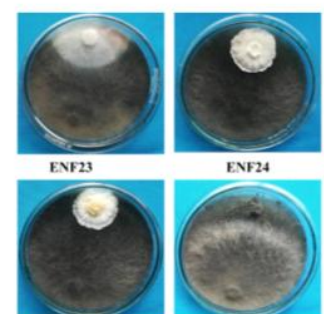

ENF24

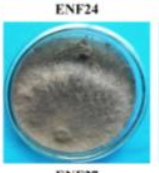

ENF26
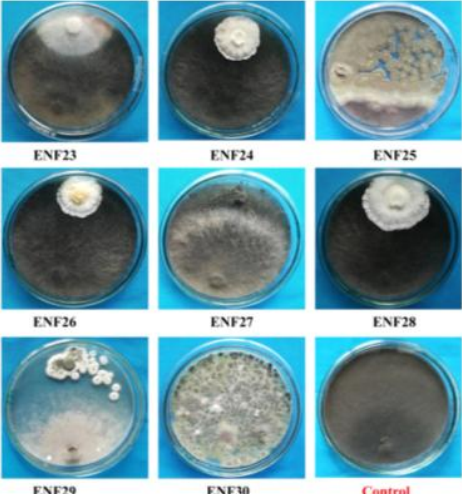

ENF25

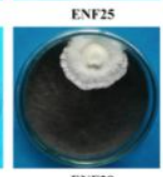

ENF28

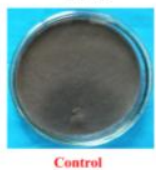




\section{Plate.2 Mechanisms of antifungal activity}

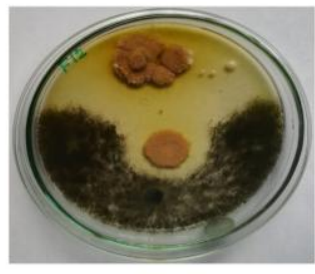

Antibiosis (ENF12)

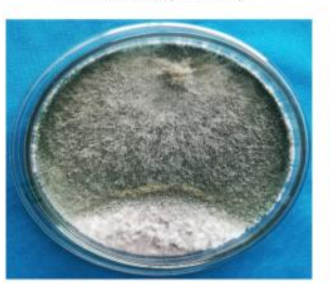

Mycoparasitism (ENF13 and ENF20)

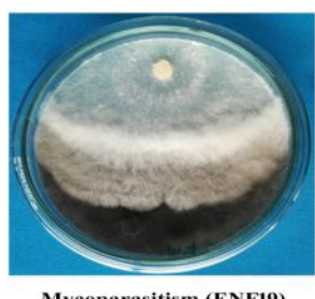

Mycoparasitism (ENF19)

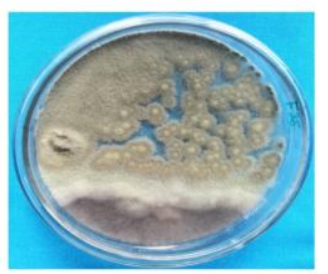

Competition for substrate (ENF25
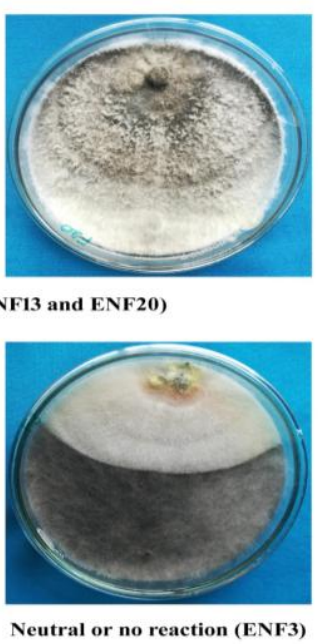

The antibiosis was due to the production of bioactive compounds which revealed that if such compounds were present in the host plant; this could contribute a defense mechanism against fungal pathogens. Similarly, the bioactive elements produced by endophytic fungi against plant pathogenic fungi was reported in many crops (Liu et al., 2001; Park et al., 2005; Inácio et al., 2006; Kim et al., 2007).

In this study, ENF25 isolate suppressed the growth of pathogen by faster growth thus creates the competition for substrate. Endophytes improved plant health as producing competition for the nutrients with pathogens in colonized plant (Compant et al., 2010). The endophytic fungi from elm such as Neofusiccocum luteum and Sordaria sp. smothered the extension of the pathogen's colony through a faster growth by competition for the substrate (Blumenstein, 2015). The overall competitive ability of a species perhaps referable to a combination of factors involving growth rates, metabolite production, niche overlap and interactions with environmental conditions (Lee and Megan, 1999). The antagonism by competition was studied by Mendoza et al. (2015) who documented that the antagonistic Trichoderma sp. stopped the growth of $M$. phaseolina at the site of contact by forming a barrier that prevents pathogen development.

In the present study, ENF13, ENF19 and ENF20 isolates showed mycoparasitism against M. phaseolina. These isolates were over grown on the pathogen's colony. ENF27 endophytic isolate was failed to antagonize the pathogen in this case pathogen over grow on endophyte. Fungal endophytes parasitized around the hyphae of pathogens by various means such as coiling, twisting, penetrating the hyphae of pathogens and secreting lyase to decompose the cell wall of pathogens. Microbial predations are the one of the mode 
of action of endophytes to suppress the plant pathogens (Gao et al., 2010). On the other hand, hyperparasitism doesn't confirm the parasitism behaviour based on the visual observations. In this case, mycoparasitism determined which "won" or "lost" the interaction and by which type of activity. Endophytes were considered to win if they inhibited the growth of the pathogen, showed more mycelial growth than the pathogen, or parasitized the pathogen. Endophytes were considered to "lose" if the pathogen "won" (showed the reverse outcome). In this work, many of the tested endophytic fungal isolates did not showed inhibition against pathogen. ENF3 and ENF5 isolates displayed neutral growth. In dual plate assay, if there was no visible interaction or "neutral" interaction, the endophyte was not examined further and thus could be excluded at an early stage of the investigations (Mejia et al., 2008) (Plate 2).

\section{References}

Aramsirirujiwet, Y., Gumlangmak, C. and Kitpreechavanich, V. 2016. Studies on antagonistic effect against plant pathogenic fungi from endophytic fungi isolated from Hottuynia cordata Thunb. and screening for siderophore and indole-3-acetic acid production. Khon Kaen University Research Journal. 21(1): 55-66.

Begum, N., Kiran, B. R., Purushothama, R. 2018. Mulberry cultivation practices and diseases: An overview. International Journal of Current Engineering and Scientific Research 5(2) : 2394-2397.

Blumenstein, K. 2015. Endophytic fungi in elms implications for the integrated management of Dutch Elm disease. Doctoral Thesis, Swedish University of Agricultural Sciences Alnarp \& Bangor University, UK 2015.

Compant, S., Clément, C. and Sessitsch, A.
2010. Plant growth-promoting bacteria in the rhizo and endosphere of plants: Their role, colonization, mechanisms involved and prospects for utilization. Soil Biology and Biochemistry. 42(5) : 669-678.

Dennis, C., and Webster, J. 1971. Antagonistic properties of speciesgroups of Trichoderma: Production of non-volatile antibiotics. Transactions of the British Mycological Society. 57: 25-39.

Domsch, K. H., Gamas, W. and Anderson, T. H. 1980. Compendium of Soil Fungi, Academic press, New York. Pp 168169, 540, 559-560.

Duncan, D. B. 1955. Multiple range and multiple F- test. Biomerical journal. 11: 1-42.

Fokkema, N.J., 1976. Antagonism between fungal saprophytes and pathogens on aerial plant surfaces in microbiology of aerial plant surfaces, eds Dickinson, Preece T. F., editors. (London: Academic Press). Pp 487-505.

Gao, F.K., Dai, C. C. and Liu, X. Z. 2010. Mechanism of fungal endophytes in plant protection against pathogen. African Journal of Microbiological Research. 4(13): 1346-1351.

Gomez, K.A., and Gomez, A. A. 1984. Statistical procedures for Agricultural Research, Wiley and Sons, New York: Pp 108-127.

Inácio, M. L., Silva, G. H., Teles, H. L., Trevisan, H. C., Cavalheiro, A. J., Bolzani, V. S., Young, M. C. M., Pfenning, L. H. and Araujo, A. R. 2006. Antifungal metabolites from Colletotrichum gloeosporioides, an endophytic fungus in Cryptocarya mandioccana Nees (Lauraceae). Biochemical Systematics and Ecology. 34: 822-824.

Ji, X., Lu, G., Gai, Y., Zheng, C. and Mu, Z. 2008. Biological control against 
bacterial wilt and colonization of mulberry by an endophytic Bacillus subtilis strain. FEMS Microbiology Ecology. 65 : 565-573.

Kannan, K.P., Basheed, M. I. A., Kannadhasan, S., Pondurai, S. and Dhakshinamoorthy, M. 2013. Mycoendophytes isolated from Mimusops elengi. L - A first report. International Biological and Biomedical Journal. 3(1): 25-29.

Kim, H.Y., Choi, G. J., Lee, H .B., Lee, S.W., Kim, H. K., Jang, K. S., Son, S. W., Lee, S. O., Cho, K. Y., Sung, N. D. and Kim, J. C. 2007. Some fungal endophytes from vegetable crops and their anti-oomycete activities against tomato late blight. Letters in Applied Microbiology. 44: 332-337.

Kumar, V., and Gupta, V. P. 2004. Scanning electron microscopy on the perithecial development of Phyllactinia corylea on mulberry-II. Sexual stage. Journal of Phytopathology. 152 : 169-173.

Kumari, N.V., 2014. Ecofriendly technologies for disease and pest management in mulberry-A review. Journal of Agriculture and Veterinary Science. 7(2): 01-06.

Lee, H.B. and Magan, N. 1999. Environmental factors and nutritional utilization patterns affect niche overlap indices between Aspergillus ochraceus and other spoilage fungi. Letters in Applied Microbiology. 28(4): 300-304.

Liu, C. H., Zou, W. X., Lu, H. and Tan, R. X. 2001. Antifungal activity of Artemisia annua endophyte cultures against phytopathogenic fungi. Journal of Biotechnology. 88 : 277-282.

Lu, Y., Chen, C., Chen, H., Zhang, J. and Chen, W. 2012. Isolation and identification of endophytic fungi from Actinidia macrosperma and investigation of their bioactivities.
Evidence-Based Complementary and Alternative Medicine. 4: 1-8.

Mejía, L.C., Rojas, E. I., Maynard, Z., Van Bael, S, Arnold, A. E., Hebbar, P., Samuels, G. J., Robbins, N. and Herre, E. A. 2008. Endophytic fungi as biocontrol agents of Theobroma cacao pathogens. Biological Control. 46(1) : 4-14.

Mendoza, J.L. H., Pérez, M. I. S., Prieto, J. M. G., Velásquez, J. D. Q., Olivares, J. G. G. and Langarica, H. R. G. 2015. Antibiosis of Trichoderma spp strains native to northeastern Mexico against the pathogenic fungus Macrophomina phaseolina. Brazilian Journal of Microbiology. 46(4): 1093-1101.

Nisa, H., Azra, N., Kamili, Irshad, A., Nawchoo, Bhat, M. S. and Nazir, R. 2018 Isolation and Identification of endophytic fungi from Artemisia scoparia (Asteraceae). International Journal of Theoretical and Applied Sciences. 10(1): 83-88.

Park, J. H., Choi, G. J., Lee, H. B., Kim, K. M., Jung, H. S., Lee, S. W., Jang, K. S. and Cho, K, Y. 2005. Griseofulvin from Xylaria sp. strain F0010, and endophytic fungus of Abies holophylla and its antifungal activity against plant pathogenic fungi. Journal of Microbiology and Biotechnology. 15 : 112-117.

Petrini, O., 1986. Taxonomy of endophytic fungi in aerial plant tissues. In: N.J. Fokkema and J van den Heuvel, (eds.), Microbiology of Phyllosphere. Cambridge University Press, Cambridge, UK, Pp. 175-187.

Ramalashmi, K., Vengatesh, K. P., Magesh, K., Sanjana, R., Joe, S. S. and Ravibalan, K. 2018. A potential surface sterilization technique and culture media for the isolation of endophytic bacteria from Acalypha indica and its antibacterial activity. 
Journal of Medicinal Plants Studies, 6(1): 181-184.

Schulz, B., Wanke, U., Draeger, S. and Aust, H. J. 1993. Endophytes from herbaceous plants and shrubs: effectiveness of surface sterilization methods. Mycological Research. 97: $1447-1450$.

Strobel, G., 2018. The emergence of endophytic microbes and their biological promise. Journal of fungi. 4(2): 57-68.

Sukumar, J. and Padma, S. D. 1999. Diseases of mulberry in India- Research progress and priorities. In: Advances in Mulberry Sericulture (Devaiah, M. C., Narayanaswamy, K. C. and Maribashetty, V. G. eds.), C.V.G. publications, Bangalore: Pp 152-186.

Thangavelu, R., and Gopi, M. 2015. Combined application of native Trichoderma isolates possessing multiple functions for the control of Fusarium wilt disease in banana cv.
Grand Naine, Biocontrol Science and Technology. 25(10): 1147-1164.

Tolulope, R.A., Adeyemi, A. I., Erute, M. A. and Abiodun, T. S. 2015. Isolation and screening of endophytic fungi from three plants used in traditional medicine in Nigeria for antimicrobial activity. International Journal of Green Pharmacy. 7 : 25-33.

Wilson, 1995. Endophyte-the evolution of the term, a clarification of its use and definition. Oikos. 73: 274-276.

Yu, J., Wu, Y., He, Z., Li, M., Zhu, K. and Gao, B. 2018. Diversity and antifungal activity of endophytic fungi associated with Camellia oleifera. Mycobiology. 46(2) : 85-91.

Zhang, S.D., Soltis, D. E., Yang, Y., Li, D. Z. and Yi, T. S. 2011. Multi-gene analysis provides a well-supported phylogeny of Rosales. Molecular Phylogenetics and Evolution. 60: 2128.

\section{How to cite this article:}

Maria Joncy, A., K. Angappan and Nakkeeran, S. 2019. Mycoendophytes and its Antifungal Efficacy against Macrophomina phaseolina (Tassi) Goid. Incitant of Mulberry (Morus indica L.) Charcoal Rot. Int.J.Curr.Microbiol.App.Sci. 8(07): 2744-2755. doi: https://doi.org/10.20546/ijcmas.2019.807.336 